\title{
DIAGNOSIS DAN TATA LAKSANA DINI SINDROM SEROTONIN BERAT
}

\author{
Nur Susiawanty ${ }^{1}$, Faisal Muhtar ${ }^{2}$ \\ ${ }^{1,2}$ Program Pendidikan Konsultan Intensive Care Fakultas Kedokteran Universitas Hasanuddin, \\ Makassar, Indonesia \\ RSUP Wahidin Sudirohusodo Makassar \\ Email: ${ }^{\text {susieadin@yahoo.co.id }}$
}

\begin{abstract}
Abstrak
Sindrom serotonin merupakan reaksi obat merugikan yang berpotensi mengancam jiwa akibat penggunaan obat agen serotonergik. Obat yang dapat menyebabkan sindrom serotonin adalah obat yang biasa digunakan dalam praktek klinis, termasuk analgetik golongan opioid dan anti emetik. Obat serotonergik dapat menyebabkan sindrom serotonin baik oleh penggunaan secara tunggal maupun kombinasi beberapa obat dengan dosis terapeutik. Dilaporkan kasus sindrom serotonin berat pada pasien paska operasi Seksio Cesarea dengan dengan riwayat penggunaan agen serotonergik antiemetik ondansetron dan analgetik opioid fentanyl dan petidin dengan dosis terapeutik, yang memerlukan perawatan intensif (ICU).Telah dilaporkan sebuah kasus keberhasilan penatalaksanaan Sindrom serotonin berat yang diduga akibat kombinasi obat serotonergik Ondansetron dan opioid serotonergik Fentanyl dan Petidin di ICU. Diharapkan para dokter terutama dokter spesialis anestesi dan intensivist mengenali gejala, penyebab dan kriteria diagnostik sindrom serotonin serta mampu melakukan tatalaksana cepat dan tepat pada sindrom serotonin untuk mempercepat resolusi dan mencegah komplikasi.
\end{abstract}

Kata kunci: Infeksi inraabdomen, Sepsis, AKI, CRRT.

\section{Pendahuluan}

Sindrom serotonin (SS) (juga disebut sebagai toksisitas serotonin) adalah toksidrom yang diinduksi oleh obat yang berpotensi mengancam jiwa yang terkait dengan aktivitas serotonergik yang meningkat baik di perifer (SST) dan sistem saraf pusat (SSP). ${ }^{1}$

Sindrom serotonin pertama kali dijelaskan pada tahun 1950-an sebagai suatu interaksi obat MAOI iproniazid (yang kemudian digunakan sebagai terapi Tuberkulosis) dengan petidin, dengan gejala sianosis berat, diaphoresis, takikardi, klonus pergelangan kaki, dan refleks berlebihan setelah diberikan meperidine $100 \mathrm{mg}$. ${ }^{2.3}$

Penggunaan pertama istilah SS muncul tahun 1980, menggambarkan fitur karakteristik pada tikus. Dua tahun kemudian, pada tahun 1982, kasus kontemporer pertama pada manusia dilaporkan oleh Insel dkk, diikuti oleh banyak laporan dan tinjauan kasus setelahnya. ${ }^{4,5}$

Sindrom serotonin diamati pada semua kelompok usia, dari neonatus sampai orang tua, dengan insiden yang meningkat yang seiring dengan cenderung meningkatnya penggunaan obat serotonergik dalam praktek klinis. ${ }^{1,6}$

Insiden sindrom serotonin dilaporkan 14$16 \%$ pada pasien yang overdosis dengan agen SSRI tunggal. Namun, insiden sindrom serotonin telah meningkat dalam 20 tahun terakhir karena perkembangan kriteria diagnostik, penggunaan agen SSRI yang luas, munculnya varian SSRI yang lebih baru, dan polifarmasi. $^{2}$

\section{Laporan Kasus}

Pasien perempuan (Ny. RN), umur 32 tahun, berat badan (BB) 70 kilogram (kg), masuk ke Rumah Sakit Tajuddin Chalid 
Makassar (RSTC), tanggal 10 Desember 2020, melalui Poliklinik Obstetri dan Ginekologi, direncanakan untuk menjalani operasi Seksio Cesaria elektif esok harinya, tgl 11 Desember 2019 pukul 10.00 WITA. Pada anamnesa didapatkan pasien dengan riwayat operasi seksio cesarea 2 tahun sebelumnya (tahun 2017) karena Ketuban Pecah Dini, di RSTC dengan anestesi Sub Arachnoid Block (SAB), tanpa penyulit dan komplikasi. Selama kehamilan yang sekarang, pasien rutin melakukan pemeriksaan Ante Natal Care di Praktek Dokter spesialis kandungan yang sama dengan dokter yang merawat di rumah sakit dengan hasil kontrol tidak ada kelainan pada kehamilan yang sekarang. Pasien dengan riwayat sering mengkonsumsi obat anti mual/muntah yaitu ondansetron tablet 2 x 4-8 mg sejak kehamilan trimester 1 kehamilan yang sekarang (kurang lebih selama 9 bulan), sampai saat dirawat di rumah sakit yang sekarang. Obat diberikan oleh dokter ahli kandungan yang merawat pasien tersebut. Pasien tidak memiliki riwayat asma maupun riwayat alergi obat sebelumnya. Pasien tidak memiliki riwayat mengkonsumsi obat anti-psikotik atau obat penenang sebelumnya. Pasien tidak ada riwayat nyeri kronik atau riwayat gangguan kejiwaan atau depresi sebelumnya. Dari pemeriksaan fisis didapatkan tidak ada kelainan. Dari pemeriksaan penunjang (tgl 9 Desember 2020) didapatkan, hasil laboratorium White Blood Count (WBC) dengan nilai 11.400, Hemoglobin 10.5, hasil swab PCR tgl 9
Desember 2020 negatif, dan nilai laboratorium lain dalam batas normal. Pasien didiagnosa dengan G2P1A0 gravid 38-39 minggu + post SC anak pertama pro SSTP elektif tgl 11 Desember 2020 pukul 10.00 WITA. Dari assesment pre anestesi didapatkan pasien termasuk kelas 2 untuk klasifikasi status fisik ASA (Physical Status American Society of Anesthesiologists), dengan leukositosis dan anemia, dan direncanakan untuk dilakukan anestesi Sub Arachnoid Block. Pasien dirawat di ruang perawatan OBGYN. Pasien mendapatkan penjelasan tentang teknik, akibat, resiko, komplikasi serta alternatif tindakan anestesi yang direncanakan esok hari dan telah mendapatkan persetujuan dari pasien dengan disaksikan oleh keluarga (suami pasien) dan bidan rumah sakit.

Tanggal 11 Desember 2020, di kamar operasi, pasien diberi premedikasi Ondansetron $4 \mathrm{mg}$ intravena, lalu dilakukan anestesi Spinal (SAB) dalam posisi left lateral decubitus (LLD) dengan menggunakan agen Bupivacain hiperbarik 0,5\% $10 \mathrm{mg}$ dengan adjuvan fentanyl $25 \mathrm{mcg}$. Hemodinamik pasien stabil selama operasi, pasien tidak disedasi sesuai dengan permintaan pasien. Operasi berjalan kurang lebih 45 menit, pasien lalu ditransfer ke ruang Post Anesthesia Care Unit (PACU).

Setelah 10 menit kemudian di PACU, pasien menggigil lalu diberikan warmer blanket suhu 38 derajat dan suplemen oksigen nasal kanul 2 liter per menit, pasien merasa 
agak baikan sedikit tapi masih menggigil. Selanjutnya suhu warmer blanket dinaikkan 42 derajat, tapi pasien masih mengeluh menggigil. Setelah 5 menit sejak menggigil pertama, pasien belum ada perbaikan, maka diberikan injeksi Pethidin $25 \mathrm{mg}$ intravena. Sesaat kemudian pasien mengeluh sesak napas dan dada terasa berat, pasien tampak gelisah, takipneu (laju napas 24 kali per menit, saturasi oksigen $96 \%$ dengan oksigen nasal kanul 2 liter per menit) dan tampak diaforesis. Sesaat kemudian, pasien gelisah, meracau lalu mengamuk dan tidak kooperatif dengan perawat PACU. Pasien kemudian tampak tremor, kejang mioklonus, dan otot sangat kaku, tapi hanya terlihat pada ekstremitas atas saja, karena masih ada efek anestesi spinal sebelumnya. Tekanan darah meningkat dari tekanan darah dasar paska operasi 110/75 mmHg menjadi 189/100 mmHg, nadi juga naik dari $76 \mathrm{x} /$ menit menjadi $147 \mathrm{x} /$ menit. Pasien diberikan injeksi Midazolam $3 \mathrm{mg}$ intravena dan injeksi Dexamethasone $5 \mathrm{mg}$ intravena dan diberikan suplemen oksigen Non Rebreathing Mask 10 liter per menit, pasien tampak lebih tenang dan saturasi oksigen naik menjadi 99\%. Kemudian dilakukan pengukuran suhu dan menunjukkan suhu naik menjadi $39,8^{\circ}$ C. Diputuskan diberikan rehidrasi cairan dengan RL 300 cc dan Paracetamol 1 gram drips intravena. Setelah 15 menit, suhu tetap naik menjadi

$40,5^{\circ} \mathrm{C}$, pasien mulai gelisah dan mengamuk lagi, masih diaforesis, mata tampak klonus okular, serta sesekali masih tampak mioklonus dan tremor. Pasien diberikan Midazolam $2 \mathrm{mg}$ intravena dan diputuskan untuk ditransfer ke ICU untuk perawatan intensif lanjut.

\section{Awal Masuk ICU}

Pasien masuk ICU dari ruang Post Anesthesia Care Unit Kamar Operasi tanggal 11 Desember 2020 pukul 12.35. Dari pemeriksaan awal pasien ditemukan pemeriksaan yang bermakna yaitu :

B1: Suplemen oksigen dengan Non Rebreathing Mask 10 liter per menit RR 38x/mnt, SpO2 96-97\%, Rh -/-, Wh -/-

B2: TD 180/98 mmHg, MAP 129 mmHg, HR 148 x/mnt, reguler, lemah, Akral hangat, keringat berlebih

B3: GCS tersedasi, wajah dan badan keringat berlebih, pupil bulat Isokor, dilatasi $5 \mathrm{~mm} / 5 \mathrm{~mm}$, RC (-/-), Okular Klonus $+/+$. Temp $41{ }^{\circ} \mathrm{C}$

B4: Urin perkateter, produksi $60 \mathrm{cc} / \mathrm{jam}$ warna kuning agak pekat

B5: Tympanik, supel, datar, Peristaltik usus (+) meningkat, defekasi (-)

B6: Edema (-), sianosis (-), fraktur (-) extremitas atas berkeringat/basah dan ada tremor, ada mioklonus. Ekstremitas bawah tidak ada pergerakan, masih dalam pengaruh anestesi spinal. Bromage Score sulit dinilai.

Pasien didiagnosis dengan Post operasi Sectio Sesarea Trans Peritoneal (SSTP) dengan indikasi G2P1A0 gravid aterm + post SC anak pertama + Serotonin Syndrome et 
causa suspek kombinasi oba serotonergik (Ondansetron, Fentanyl dan Pethidin)

\section{Penatalaksanaan di ICU}

Tindakan awal di ICU mencakup:

a. Suplemen oksigen Non rebreathing Mask dinaikkan 15 liter per menit

b. Pengambilan sampel Analisa Gas Darah dan laboratorium Darah rutin dan kimia darah, laktat

c. Posisi kepala diekstensikan dan elevasi $30-45^{\circ}$

d. Injeksi Midazolam $3 \mathrm{mg}$ intravena, dan dimaintenance $1 \mathrm{mg} / \mathrm{jam} /$ syringe pump, pasien menjadi lebih tenang, tremor halus dan mioklonus ada sesekali dengan periode yang lebih singkat

e. Pemasangan Nasogastric tube (NGT), dialirkan dan keluar cairan kekuningan volume sekitar $20 \mathrm{cc}$.

f. Diberikan obat Cyproheptadine $12 \mathrm{mg}$ (1x 3 caplet) via NGT

g. Cooling dengan cooling blanket

Dari analisis gas darah diperoleh asidosis metabolik pH of 7.336, PaCO2 27.2 $\mathrm{mmHg}, \mathrm{PaO} 2$ of $315 \mathrm{mmHg}, \mathrm{SaO} 2$ of $98.4 \%$, HCO3 10 mmol/L, BE -16, Na+ 137 mEq/L, $\mathrm{K}+$ of $4.46 \mathrm{mEq} / \mathrm{L}$ dan $\mathrm{Cl} 100 \mathrm{mmol} / \mathrm{L}$. Kadar laktat tinggi, yaitu $12,3 \mathrm{mmol} / \mathrm{L}$.

Hasil laboratorium Darah Rutin menunjukkan leukositosis 18.500 dan trombosit 177.000. Hasil Kimia Darah menunjukkan Ureum 102 umol/L, kreatinine meningkat $1,54 \mathrm{mg} / \mathrm{dl}$,
Setelah 5 menit pemberian Cyproheptadine via NGT, pasien tampak jauh lebih tenang, mioklonus dan tremor perlahan mulai hilang, Tanda vital pasien sudah mulai mendekati nilai normal. Tekanan darah dan nadi turun akan tetapi tetap tinggi yaitu tekanan darah sistole berkisar 140-150 mmHg, tekanan darah diastole berkisar 73-89 $\mathrm{mmHg}$ dan nadi berkisar 100-110 mmHg. Laju pernapasan sudah mulai turun mendekati normal 16-18 kali per menit, suhu badan juga sudah turun menjadi $37,8^{\circ}$ C.dan saturasi oksigen naik menjadi 100\%. Semua pakaian, alas dan seprai yang basah diganti.

Sejam kemudian, setelah keadaan pasien lebih stabil, diputuskan untuk melakukan CT-scan kepala untuk mencari adakah proses intrakranial yang menyebabkan gejala neurologis. Dilakukan juga pemeriksaan foto thorax dan hasilnya tidak ditemukan adanya kelainan. Pasien stabil selama transportasi. Hasil CT- Scan kepala menunjukkan tidak ada kelainan.

Setelah 2 jam perawatan ICU, tanda vital jauh lebih normal, dimana tanda vital dalam batas normal. Diputuskan untuk tetap memberikan Cyproheptadine 8 mg per 6 jam per NGT. Midazolam mulai diturunkan 0,5 $\mathrm{mg} / \mathrm{jam} / \mathrm{syringe}$ pump, dan dihentikan 1 jam kemudian. 30 menit kemudian setelah Midazolam dihentikan, keadan pasien sudah lebih stabil, tanda vital juga tetap dalam batas normal. Pasien mulai sadar walaupun masih agak mengantuk, kontak baik dengan keluarga dan mulai mengeluh nyeri di area luka operasi, 
dengan skor nyeri NRS 3-4/10. Selama 2 jam pertama di ICU, produksi urine $100 \mathrm{cc}$ dalam 2 jam. Selanjutnya produksi urine 50-100 cc/jam.

Untuk manajemen nyeri paska operasi, diputuskan untuk memberikan analgetik Parecoxib $40 \mathrm{mg}$ per 12 jam/intravena. 10 menit kemudian, pasien kembali tidur tenang.

Observasi di ICU tetap dilanjutkan sampai esok harinya jam 06.00 dan lanjut diobservasi di HCU dalam 24 jam berikutnya lalu dipindahkan ke bangsal perawatan keesokan harinya. Terapi Cyproheptadine terakhir diberikan pkl 07.00 dan dihentikan. Analgetik post operasi dilanjutkan dengan Metamizole 1 gram/8 jam/intravena. Pasien kemudian dipulangkan 1 hari kemudian.

\section{Diskusi}

Serotonin atau 5-Hydroxytryptamine (5-HT) adalah neurotransmitter penting yang ditemukan di sistem saraf pusat dan tepi. Di sistem saraf pusat, ditemukan di nukleus raphe di batang otak. Sedangkan di perifer, di sistem saraf tepi, ditemukan dalam sel-sel enterochromaffin usus dan trombosit. ${ }^{7}$

\section{Patofisiologi Sindrom Serotonin}

Patofisiologi sindrom serotonin sangat kompleks (Gambar 1). Sindrom serotonin dapat terjadi akibat peningkatan sintesis Ltryptophan, menurunnya metabolisme oleh Monoamine Oxidase Inhibitor (MAOI), peningkatan pelepasan serotonin, meningkatnya sensitifitas reseptor serotonin, menurunnya reuptake serotonin, agonisme (baik dari peningkatan konsentrasi 5-HT atau obat-obatan yang bekerja langsung sebagai agonis reseptor), dan/atau antagonisme, dengan berbagai variasi kombinasi dari subtype-subtipe reseptor 5-HT. 3 ,

Selain agonisme postsinaptik 5-HT2A dan 5-HT1A yang berlebihan, terdapat beberapa faktor lain yang mempengaruhi sindrom serotonin, termasuk diantaranya adalah:

a. Mutasi isoform sitokrom CYP2D6 \& CYP3A4, yang merupakan modulatormodulator kunci metabolisme serotonin. ${ }^{9}$

b. Hipersensitivitas reseptor serotonin dari varian-varian gen sambungan, polimorfisme alel, dan mutasi reseptor. 9

c. Penghambatan CYP2D6 dan CYP3A4, yang menurunkan metabolisme serotonin. $^{3}$

d. Inhibisi reuptake norepinefrin, blokade N-metil-D-aspartat,inhibisi $\quad \gamma$-amino butyric-acid (GABA), dan antagonisme 5-HT3 yang juga berperan dalam presipitasi sindrom serotonin. ${ }^{4,10-13}$

\section{Obat-obatan yang terkait dengan}

\section{Sindrom Serotonin}

Terdapat daftar agen atau obat yang berpotensi menyebabkan sindrom serotonin melalui berbagai mekanisme seperti terlihat pada Gambar $1 .^{3}$

Meskipun SS telah dijelaskan bisa terjadi akibat overdosis obat tunggal, dan pada SS ringan hingga sedang, kadang diakibatkan 
oleh peningkatan dosis terapeutik pada individu yang rentan atau sensitif. SS berat biasanya hanya terjadi akibat pemberian secara bersama-sama 2 atau lebih obat serotonergik (meskipun pada dosis terapeutik).

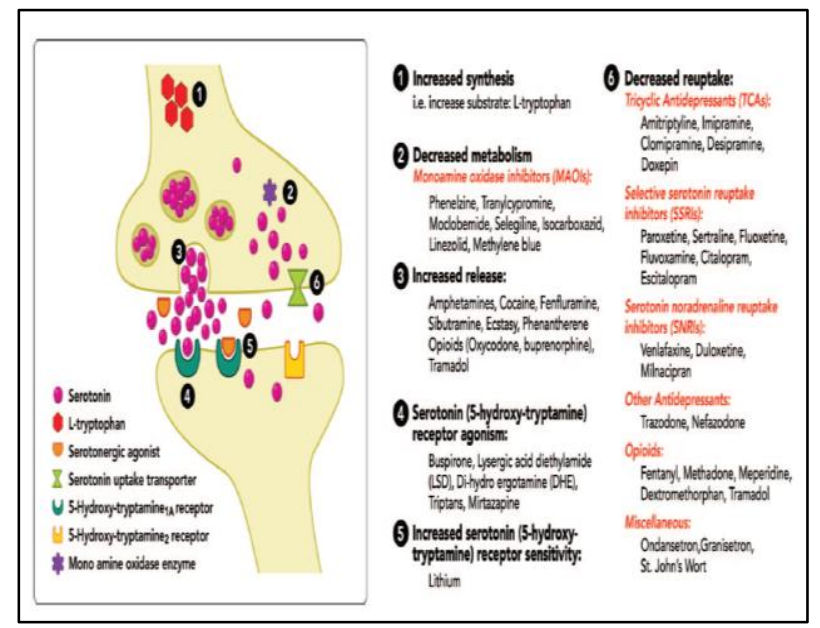

Gambar 1. Mekanisme Peningkatan Kadar Serotonin dan Agen-agen Serotonergik yang Terkait ${ }^{3}$

Pada pasien ini terjadi SS berat yang diduga akibat kombinasi lebih dari 2 obat serotonergik, meskipun dengan dosis terapeutik.

Interaksi obat farmakokinetik juga terlibat melalui inhibisi jalur sitokrom P450, sebuah jalur yang dihambat oleh SSRI sendiri (khususnya CYP2D6 dan CYP3A4). Setidaknya 25 obat-obat serotonergik dimetabolisme oleh jalur sitokrom P450, dan penelitian terbaru telah menunjukkan 50\% dari 20 obat-obat teratas yang terkait dengan SS telah diketahui interaksi farmakokinetiknya dimana pemberian bersama inhibitor sitokrom P-450 dapat meningkatkan konsentrasi obat menjadi level toksik. ${ }^{1}$ Hal tersebut konsisten dengan hipotesis bahwa SS adalah efek merugikan yang dose-dependant dimediasi oleh kombinasi peningkatan serotonin endogen intrasinaptik atau ekstrasinaptik dan aktivasi reseptor 5-HT baik langsung ataupun tidak langsung. Namun, fakta bahwa berbeda pasien menunjukkan gejala SS dengan dosis obat dan / atau kombinasi obat yang berbeda, menunjukkan bahwa mungkin juga ada faktor genetik yang mendasari yang memodulasi kerentanan terjadinya SS. Faktor-faktor genetik dapat mencakup polimorfisme di jalur CYP450, gen SERT, serta reseptor 5-HT2. ${ }^{1}$

Pada pasien ini bisa saja terdapat faktor genetik atau farmakodinamik dasar yang menyebabkan terjadinya SS mengingat dosis ketiga serotonergik adalah dosis biasa dan rutin diberikan pada praktek klinik pada pasien lain tapi tidak sampai menimbulkan gejala SS seperti yang terjadi pada pasien ini. Akan tetapi tidak dilakukan pemeriksaan faktor genetik tersebut karena tidak tersedianya modalitas pemeriksaan tersebut.

Ondansetron merupakan obat golongan antagonis 5-HT3. Sejak tahun 2012, WHO, FDA dan kemudian diikuti oleh Health Canada pada tahun 2014, telah merilis laporan yang menyimpulkan bahwa terdapat resiko potensial terjadinya sindrom serotonin ketika obat antagonis 5-HT3 digunakan bersamasama dengan obat-obat serotonergik. Mekanisme yang diduga menyebabkan efek tersebut adalah peningkatan kadar serotonin bebas dihasilkan oleh 'perpindahan' serotonin yang 'bebas' karena tidak mampu mengikat reseptor 5-HT3 yang telah diblokir oleh ondansetron, sehingga meningkatkan kadar serotonin bebas yang berikatan dengan 
subtipe-subtipe reseptor serotonin yang lain, termasuk 5-HT1A dan 5-HT2A. ${ }^{14-16}$

Sindrom serotonin telah dikaitkan dengan beberapa opioid atau kombinasi opioid dengan obat serotonergik lain dalam berbagai laporan kasus. ${ }^{4}$ Mekanisme aksi serotonergik opioid adalah inhibisi lemah reuptake serotonin (SERT) dan peningkatan pelepasan serotonin intrasinaptik melalui penghambatan inhibitor neuron GABA-nergik presinaptik pada neuron serotonin. ${ }^{3}$

Fentanyl merupakan obat analgetik opioid yang paling disukai dan paling sering digunakan, terutama oleh dokter anestesi Fentanyl adalah suatu agonis 5-HT1A, yang meningkatkan pelepasan serotonin, dan melalui penghambatan reuptake serotonin yang lemah, meningkatkan kadar serotonin intrasinaptik kadar serotonin. ${ }^{2,3}$

Dari database WHO VigiBase, dilaporkan Fentanyl merupakan obat analgetik opioid kedua setelah tramadol, yang paling banyak dilaporkan dengan 363 kasus. Dari 147 kasus, dimana opioid merupakan satu-satunya suspek penyebab SS, fentanyl adalah obat ketiga yang terbanyak dilaporkan dengan 19 kasus. $^{2}$

\section{Keterlibatan Meperidine dengan} sindrom serotonin disebabkan oleh adanya inhibisi SERT-manusia-diamati pada transfeksi sel-sel ginjal manusia oleh meperidine pada konsentrasi molar rendah.

Eksperimen lain juga menunjukkan bahwa meperidine terikat dengan reseptor 5-HT2A manusia pada konsentrasi plasma dosis terapeutik., dan kemungkinan memicu aktivasi langsung reseptor selain menghambat SERT. Database Vigibase WHO menunjukkan 66 kasus (4\%) meperidine terkait SS ketika digunakan tunggal atau bersama dengan obatobatan lain. $^{2}$

\section{Diagnosa Sindrom Serotonin}

Sindrom serotonin merupakan suatu tantangan diagnostik karena gejala klinisnya yang bervariasi dan tumpang tindih satu dengan yang lain. Hal ini diperburuk lagi oleh kurangnya kepekaan dan awamnya dokter dan tenaga medis lain terhadap sindrom ini, terbatasnya kriteria diagnostik, dan perbedaan metabolisme serotonin. ${ }^{1,3}$

Diagnosa SS harus dibuat berdasarkan anamnesa yang seksama, untuk mendapatkan informasi tentang adanya riwayat konsumsi atau penggunaan agen-agen serotonergik (baik obat dengan resep, obat bebas, obat herbal, dan obat-obatan terlarang) disertai dengan pemeriksaan fisis, terutama pemeriksaan neurologis yang akurat. Dugaan tinggi diagnosis SS apabila dari anamnesa didapatkan informasi penggunaan agen serotonergik dan adanya kondisi medis dan kondisi psikiatri lain dari pasien. Harus sangat dicurigai adanya diagnosis SS pada pasien dengan riwayat terapi obat yang mendukung ke arah SS disertai adanya satu atau lebih kombinasi dari gambaran klinis klasik. ${ }^{1,3}$ Dari anamnesa pasien ini didapatkan bahwa ada

riwayat terpapar dengan agen serotonergik, yaitu Ondansetron sebagai antagonis 5-HT3, dan opioid serotonergik yaitu Fentanyl dan 
Pethidin. Ondansetron tablet bahkan digunakan dalam jangka waktu lama, yaitu selama kurang lebih 9 bulan kehamilan terakhir dan juga mendapatkan Ondansetron intravena sebagai premedikasi pra anestesi di kamar operasi. Fentanyl intravena didapatkan di kamar operasi sebagai adjuvan anestesi spinal dan Pethidin intravena didapatkan saat di PACU sebagai terapi menggigil.

Gejala SS biasanya muncul dalam 6 jam setelah konsumsi obat atau kombinasi obat (60\% kasus), biasanya bila obat diberikan dengan cepat atau dalam dosis besar termasuk overdosis. Sekitar $25 \%$ pasien muncul gejala setelah lebih 24 jam (biasanya bila terapi dititrasi secara bertahap dan/atau crosstapered). Pada sebagian kecil pasien (7\% pasien), beberapa diantaranya pasien geriatri, onset gejala mungkin terlambat sampai beberapa hari. ${ }^{1,3}$ Pada pasien ini gejala SS mulai muncul segera setelah pemberian obat opioid serotonergik yaitu Pethidin, sekitar 1 jam setelah pemberian obat opioid serotonergik Fentanyl adjuvan intratekal anestesi spinal dan setelah kurang lebih 1 jam setelah pemberian ondansetron intravena.

Gambaran klinis SS sangat bervariasi mulai dari gejala ringan hingga berat yang mengancam nyawa, yang mencerminkan kombinasi dari tingkat aktivitas serotonergik berlebihan di SSP, atau subtipe reseptor 5-HT tertentu yang diaktifkan (langsung atau tidak langsung). ${ }^{1}$

Trias klasik dari gambaran klinis SS adalah: ${ }^{1,3,18}$ a. Perubahan status mental (termasuk kecemasan, agitasi, halusinasi visual, kebingungan, disorientasi dan koma)

b. Instabilitas sistem saraf otonom (termasuk diaphoresis, takikardi, takipnu, hipertermia, midriasis, hipertensi, muntah dan diare)

c. Abnormalitas neuromuskuler (kekakuan otot, hiperkinesis termasuk mioklonus dan tremor, hiperrefleksia, nystagmus, okular klonus, ataksia, trismus, dan tanda Babinski bilateral).

Hiperrefleksia dan klonus biasanya lebih menonjol di anggota tubuh bagian bawah dan ini merupakan petunjuk yang mendasari diagnosis sindrom ini. ${ }^{1}$

Pada pasien ini didapatkan gejala SS yaitu perubahan status mental yaitu agitasi lalu delirium, Instabilitas otonom yaitu hipertermi, diaforesis, takikardi, hipertensi, pupil dilatasi dan tidak adanya refleks cahaya langsung pada pupil dan eksitabilitas neuromuskuler yang spontan yaitu mioklonus dan tremor ekstremitas atas dan klonus okular.

Tidak ada abnormalitas nilai laboratorium yang spesifik untuk sindrom serotonin. Kadar serotonin dalam darah tidak ada hubungannya dengan derajat keparahan penyakit karena tidak menggambarkan kadar serotonin intrasinaptik. Beberapa abnormalitas laboratorium berhubungan dengan hipertonisitas muskuler dan kemungkinan adanya rhabdomiolisis pada kasus toksisitas serotonin berat. ${ }^{1,3.5}$ 
Pada pasien ini didapatkan hasil lab yang bermakna yaitu dari analisis gas darah diperoleh asidosis metabolik dan kadar laktat tinggi, yaitu 12,3 mmol/L. Hasil laboratorium Darah Rutin menunjukkan leukositosis 18.500 dan trombosit 177.000. Hasil Kimia Darah menunjukkan Ureum 102 umol/L, kreatinine meningkat $1,54 \mathrm{mg} / \mathrm{dl}$, akan tetapi kesemua abnormalitas nilai laboratorium tersebut hanya berhubungan dengan hipertonisitas muskuler akibat toksisitas serotonin yang berat pada pasien ini, yang segera berangsur membaik menuju nilai normal seiring dengan menghilangnya gejala klinis SS. Pada pasien ini dilakukan pemeriksaan CT Scan kepala setelah pasien stabil dan tenang, dan didapatkan hasil tidak didapatkan adanya kelainan. Pada pasien ini tidak dilakukan pemeriksaan EEG karena tidak tersedianya modalitas tersebut di rumah sakit kami.

Karena tidak adanya tes laboratorium yang spesifik, maka telah diterbitkan beberapa kriteria diagnostik untuk SS. Terdapat 3 sistem kriteria diagnostik yang tersedia, yaitu Sternbach Criteria (SC), Radomski Criteria (RC), dan Hunter Serotonin Toxicity Criteria (HSTC), yang kesemuanya mencoba merefleksikan gejala dan sekumpulan gejala yang dianggap karakteristik untuk toksisitas serotonin yaitu SS. Kriteria terbaru dan paling sering digunakan adalah HSTC (Gambar 4) $)^{1,19}$ Dibandingkan dengan SC, HSTC lebih mudah digunakan, lebih sensitif ( $84 \%$ vs $75 \%$ ), dan sedikit lebih spesifik (97\% vs $96 \%){ }^{3}$
Dengan menggunakan kriteria diagnostik HSTC, didapatkan bahwa pasien ini memenuhi kriteria untuk dikatakan menderita sindrom serotonin. Pasien terpapar dengan agen serotonergik yaitu ondansetron, Fentanyl dan Pethidin. Kriteria terkait dengan kelompok gejala klonus okular, agitasi dan diaforesis. Karena memenuhi kedua kriteria tersebut maka dapat dikatakan pada pasien ini menderita Sindrom Serotonin.

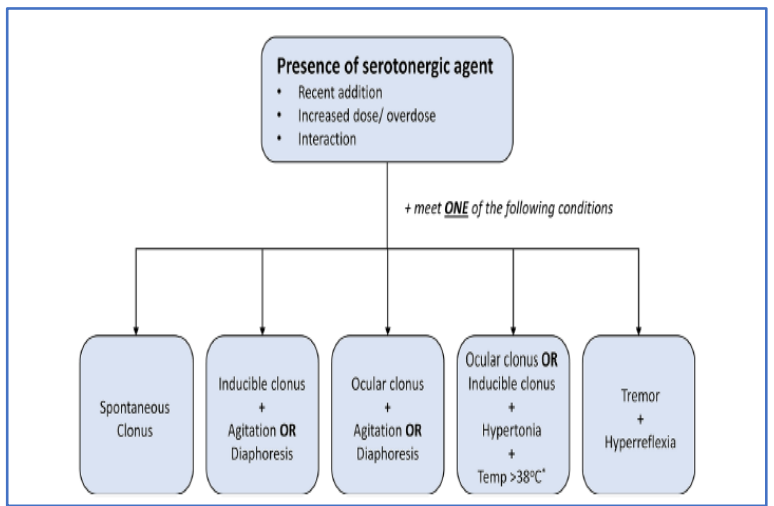

Gambar 4. The Hunter Serotonin Toxicity Criteria (Kriteria toksisitas serotonin Hunter) : untuk diagnosis sindrom serotonin. ${ }^{1}$

Diagnosis banding untuk SS termasuk toksidrom lain seperti NMS, hipertermia maligna, dan toksisitas antikolinergik (Tabel 3), serta kondisi seperti meningitis, ensefalitis (khususnya ensefalitis autoimun), overdosis simpatomimetik, hipertermia sentral, dan sengatan panas (heatstroke).

Bila SS ditandai dengan hiperaktivitas neuromuskuler (hyperreflexia dengan klonus, mioklonus, dan tremor), pada NMS biasanya ditemukan penurunan aktivitas neuromuskuler dengan fitur ekstrapiramidal (bradikinesia, rigiditas lead-pipe, dan rigiditas roda gigi/rigwheel rigidity). Pada NMS jarang ditemui gejala hyperreflexia dan klonus, 
dimana klonus merupakan gejala khas dalam menegakkan diagnosis SS dengan HSTC. Onset NMS yang lebih lambat selama beberapa hari hingga beberapa minggu sementara SS berkembang lebih cepat (dalam 6 jam, umumnya dalam waktu 24 jam). ${ }^{1,5}$

Gejala klinis yang membedakan toksisitas kolinergik dari SS adalah tonus otot dan refleks normal, serta kulit kering dan bising usus yang menurun. ${ }^{1,5}$

Hipertermia maligna terjadi pada orang yang rentan secara genetik, dalam beberapa menit, akibat terpapar oleh halogenasi agen anestesi inhalasi dan pelumpuh otot golongan depolarisasi (seperti suksinilkolin) selama atau setelah operasi. Gejalanya yang membedakan dari SS adalah kekakuan otot seperti rigormortis. $^{1,5}$

\section{Penatalaksanaan Sindrom Serotonin}

Dua komponen utama penatalaksanaan SS yang optimal adalah perawatan suportif yang baik (terutama pada kasus yang parah) dan penilaian risiko dan pemantauan ketat pasien dengan gejala ringan hingga sedang untuk menghindari perkembangan menjadi parah dan mengancam jiwa. ${ }^{1}$

Langkah pertama adalah mengidentifikasi dan menghentikan obat-obat serotonergik, dan perawatan suportif untuk menstabilkan tandatanda vital.

Komponen utama terapi suportif SS termasuk sedasi untuk mengurangi aktifitas otot, pendinginan aktif (termasuk kipas angin, semprotan air, kompres es, kristaloid dingin, atau selimut pendingin), dan dalam kasus yang berat menggunakan pelumpuh otot dan ventilasi mekanik di unit perawatan intensif (ICU). Pada kasus yang berat di mana suhunya lebih besar dari $41,1^{\circ} \mathrm{C}$, pasien harus segera dilumpuhkan dan diintubasi, dengan agen nondepolarisasi seperti vecuronium. Pilihan pertama agen sedasi yang biasa digunakan adalah benzodiazepin; selain dapat mengontrol agitasi juga dapat menumpulkan komponen hiperadrenergik, membantu memperbaiki peningkatan tekanan darah dan detak jantung. Dosis benzodiazepin harus dititrasi sesuai efek klinis, dengan tujuan sedasi dan pemeliharaan tanda vital normal pada pasien. $^{1}$

Pada SS berat, mencegah hipertermia dan akibatnya yaitu gagal multiorgan merupakan tujuan utama. Oleh karena peningkatan suhu tubuh lebih disebabkan oleh peningkatan aktivitas otot, bukan karena peningkatan titik setel hipotalamus (yang terlihat di pireksia), agen antipiretik memiliki sedikit efek dan tidak diindikasikan pada SS. ${ }^{1}$

Jika penggunaan strategi tersebut di atas gagal untuk mengontrol agitasi dan tandatanda vital dengan baik, maka mungkin perlu digunakan antagonis serotonin. Cyproheptadine adalah antagonis reseptor histamin-1 nonspesifik dengan 5-HT1A, 5HT2A, antagonis reseptor 5-HT2B, 5-HT2C, 5-HT3, 5-HT6, dan 5-HT7 serta beberapa efek antikolinergik lemah. ${ }^{1}$ Dosis loading awal yang dianjurkan adalah $12 \mathrm{mg}$ via oral atau dihancurkan melalui selang nasogastrik, diikuti dengan $2 \mathrm{mg}$ setiap 2 jam sampai 
terlihat perbaikan klinis. Regimen dosis alternatif yaitu merubah dosis menjadi $8 \mathrm{mg}$ setiap 6 jam sekali setelah gejala terkontrol. Cyproheptadine hanya tersedia dalam bentuk oral, tetapi mudah dihancurkan dan diberikan melalui selang nasogastrik atau orogastrik. ${ }^{4,20}$

Tatalaksana sindrom serotonin pada pasien ini adalah segera menghentikan obat agen serotonergik (ondansetron, fentanyl, pethidin) yang diduga penyebab SS saat mulai muncul gejala awal. Karena kondisi pasien tidak stabil dan dirasa memerlukan monitoring ketat dan terapi suportif tambahan maka pasien ditransfer ke ICU. Terapi suportif yang diberikan yaitu kontrol agitasi dengan sedasi menggunakan obat golongan Benzodiazepine yaitu Midazolam dosis awal dan maintenance kontinyu intravena; dan suplemen oksigen yang diberikan sejak di ruang pemulihan anestesi, kontrol hipertermi dengan cooling blanket, tanpa menggunakan obat anti piretik.

Pasien diberi terapi spesifik yaitu Antagonis 5-HT2A yaitu Cyproheptadine kapsul melalui Nasogastric Tube dengan dosis inisial $12 \mathrm{mg}$ dan dosis maintenance $8 \mathrm{mg}$ per 6 jam. Setelah 5 menit pemberian Cyproheptadine tanda vital pasien perlahan mendekati normal dan pasien perlahan menjadi tenang. Tidak diberikan terapi ikutan, karena terjadi perbaikan gejala klinis setelah terapi inisial. Terapi cyproheptadine tetap dilanjutkan sampai tiga kali pemberian dosis

maintenance yaitu $8 \mathrm{mg}$ per oral. Tanda vital pasien dan kesadaran pasien mengalami perbaikan secara signifikan. Pada pasien ini tidak dilakukan intubasi dan ventilasi mekanik karena setelah diobservasi, terjadi perbaikan yang signifikan setelah sedasi dan pemberian obat antagonis serotonin.

Penggunaan obat analgetik golongan opioid harus dihindari karena adanya efek serotonergik dari sebagian besar opioid yang biasa digunakan dalam praktik klinik. ${ }^{1}$ Nyeri paska operasi yang dirasakan pasien diputuskan untuk diterapi dengan golongan COX2-Inhibitor yaitu Parecoxib dengan dosis $40 \mathrm{mg} / 12$ jam/intravena. Analgetik pengganti tersebut bisa mengatasi nyeri paska operasi yang ditandai dengan penurunan skala nyeri pasien.

Prognosis SS ini sebenarnya baik apabila dapat dideteksi dini dan ditatalaksana secara cepat dan tepat. Pada pasien ini karena dideteksi secara cepat sebagai suatu sindrom serotonin berat, diikuti dengan penghentian agen yang diduga sebagai penyebab dan kemudian tatalaksana suportif secara cepat dan tepat dengan monitoring yang ketat di ICU, sehingga tercapai resolusi cepat dan menghindari terjadinya komplikasi berat yang mengancam nyawa.

\section{Simpulan}

Telah dilaporkan sebuah kasus keberhasilan penatalaksanaan Sindrom serotonin berat yang diduga akibat kombinasi obat serotonergik Ondansetron dan opioid serotonergik Fentanyl dan Petidin di ICU.

Diharapkan para dokter terutama dokter spesialis anestesi dan intensivist mengenali gejala, penyebab dan kriteria diagnostik 
sindrom serotonin serta mampu melakukan tatalaksana yang cepat dan tepat pada sindrom serotonin untuk mempercepat resolusi dan mencegah komplikasi.

\section{Daftar Pustaka}

1. Scotton et al. Serotonin Syndrome: Pathophysiology, Clinical Features, Management, and Potential Future Directions. Int Journal of Tryptophan Research. 2019;12: 1-14.

2. Baldo BA, Rose MA. The anaesthetist, opioid analgesic drugs, and serotonin toxicity: a mechanistic and clinical review. BJA, 2020;124 (1): 44-62.

3. Rastogi $\mathrm{R}$ et al. Case Scenario: Opioid Association with Serotonin Syndrome Implications to the Practitioners. Am Society of Anesth, 2011;115:1291-8.

4. Boyer EW, Shannon M. The serotonin syndrome. N Engl J Med. 2005;352:111220.

5. Buckley NA, Dawson AH, Isbister GK. Serotonin syndrome. BMJ. 2014;348:g1626.

6. Culbertson VL, Rahman SE, Bosen GC, Caylor ML, Echevarria MM, Xu D. Implications of off-target serotoninergic drug activity: an analysis of serotonin syndrome reports using a systematic bioinformatics approach.

Pharmacotherapy. 2018;38:888-898.

7. Saper CB. Brainstem modulation of sensation, movement, and consciousness. In: Kandel ER, Schwartz JH, Jessell TM, eds. Principles in Neural Science. 4th ed. New York: McGraw-Hill; 2000:896.

8. Isbister GK, Buckley NA: The pathophysiology of serotonin toxicity in animals and humans: Implications for diagnosis and treatment. Clin Neuropharmacol 2005; 28:205-14.

9. Pilgrim JL, Gerostamoulos D, Drummer $\mathrm{OH}$ : Review: Pharmacogenetic aspects of the effect of cytochrome P450 polymorphisms on serotonergic drug metabolism, response, interactions, and adverse effects. Forensic Sci Med Pathol. 2011; 7:162-84.

10. Gillman PK: Serotonin syndrome: History and risk. Fundam Clin Pharmacol 1998; 12:482-91.

11. Ables AZ, Nagubilli R: Prevention, recognition, and management of serotonin syndrome. Am Fam Physician 2010; $81: 1139-42$.

12. Ener RA, Meglathery SB, Van Decker WA, Gallagher RM: Serotonin syndrome and other serotonergic disorders. Pain Med 2003; 4:63-74

13. Radomski JW, Dursun SM, Reveley MA, Kutcher SP: An exploratory approach to the serotonin syndrome: An update of clinical phenomenology and revised diagnostic criteria. Med Hypotheses 2000; $55: 218-24$

14. Summary safety review-serotonin blocking drugs (serotonin antagonists) Aloxi (palonosetron), Anzemet (dolasetron), Kytril(granisetron) and 
generics, and Zofran (ondansetron) and generics- Serotonin Syndrome. Available at: $\quad$ http://www.hc-sc.gc.cal $\quad$ dhp$\mathrm{mps} /$ medeff/advisories-avis/reviewexamen/serotonin-eng.php. Accessed May 29th 2014.

15. WHO pharmaceutical newsletter: ondansetron and serotonin syndrome. 2012;3:16-21. 